Section Editor

Mitchell S.V. Elkind,

MD, MS

Mystery Case:

\title{
Cerebral amyloid angiopathy-related inflammation
}

(6)

Aaron L. Berkowitz, MD, $\mathrm{PhD}$

Jessica M. Baker, MD Julie J. Miller, MD, PhD Steven M. Greenberg, $\mathrm{MD}, \mathrm{PhD}$
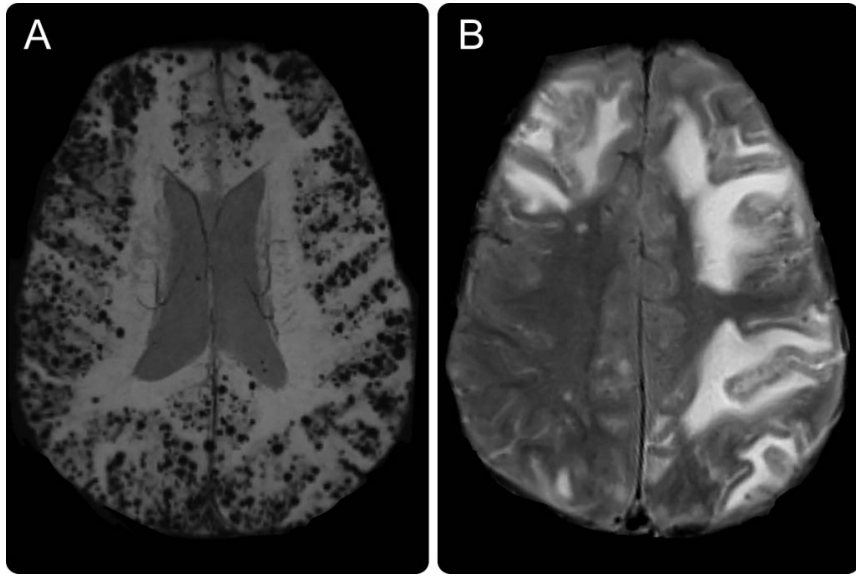

MRI demonstrates innumerable lobar microhemorrhages on susceptibility-weighted imaging sequence (A) and asymmetric subcortical T2 hyperintensities on fluid-attenuated inversion recovery sequence (B).

A 59-year-old man was arrested for unruly public behavior. He was subsequently found unresponsive with bilateral upper extremity extensor posturing and lower extremity triple flexion when stimulated. Over the next 48 hours, he awoke and became belligerent. MRI revealed innumerable cortical microhemorrhages on susceptibility-weighted imaging (figure, A) and asymmetric subcortical T2 hyperintensities (figure, B) consistent with cerebral amyloid angiopathy-related inflammation (CAA-ri). ${ }^{1}$ With corticosteroid treatment, he rapidly became calm and conversant, returning to near his premorbid baseline with only mild residual confusion within 1 week. CAA-ri is an uncommon, possibly autoimmune ${ }^{2}$ variant of CAA characterized by cognitive changes, seizures, headaches, and often, responsiveness to immunosuppressive therapy.

\section{AUTHOR CONTRIBUTIONS}

Dr. Berkowitz conceived of the manuscript, drafted the initial manuscript, revised the manuscript, created the figure, and revised the accompanying PowerPoint. Dr. Baker revised the manuscript. Dr. Miller revised the manuscript and developed the accompanying PowerPoint. Dr. Greenberg drafted the initial manuscript and revised the manuscript.

\section{STUDY FUNDING}

No targeted funding reported.

\section{DISCLOSURE}

A. Berkowitz reports no relevant disclosures. He receives royalties from Clinical Pathophysiology Made Ridiculously Simple (Medmaster, Inc.) and The Improvising Mind (Oxford University Press). J. Baker, J. Miller, and S. Greenberg report no disclosures relevant to the manuscript. Go to Neurology.org for full disclosures.

\section{REFERENCES}

1. Kinnecom C, Lev MH, Wendell L, et al. Course of cerebral amyloid angiopathy-related inflammation. Neurology 2007;68:1411-1416

2. Piazza F, Greenberg SM, Savoiardo M, et al. Anti-amyloid $\beta$ autoantibodies in cerebral amyloid angiopathy-related inflammation: implications for amyloid-modifying therapies. Ann Neurol 2013;73: 449-458.

\section{MYSTERY CASE RESPONSES}

The Mystery Case series was initiated by the Neurology ${ }^{\circledR}$ Resident \& Fellow Section to develop the clinical reasoning skills of trainees. Residency programs, medical student preceptors, and individuals were invited to use this Mystery Case as an educational tool. 
Responses were solicited through a group e-mail sent to the American Academy of Neurology Consortium of Neurology Residents and Fellows and through social media.

All the responses we received came from individuals rather than groups. Sixty percent of respondents correctly stated that the lobar microhemorrhages seen on the patient's susceptibility-weighted imaging sequence and the subcortical hyperintensities on the
T2 sequence are most consistent with CAA-ri. A total of $47 \%$ of respondents correctly identified corticosteroid therapy as the treatment of choice for this condition.

This case highlights the importance of MRI in diagnosing this rare, but often treatable, variant of CAA.

Andrew Schepmyer, MD

University of British Columbia, Vancouver, Canada

\section{This Week's Neurology ${ }^{\circledR}$ Podcast}

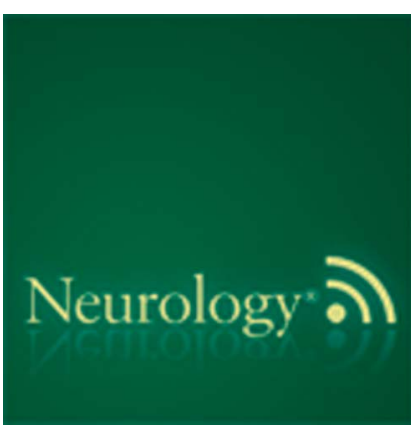

Mystery Case: Cerebral amyloid angiopathy-related inflammation (See p. 1678)

This podcast begins and closes with Dr. Robert Gross, Editor-inChief, briefly discussing highlighted articles from the October 28, 2014, issue of Neurology. In the second segment, Dr. Prachi Mehndiratta talks with Dr. Aaron Berkowitz about his paper on cerebral amyloid angiopathy-related inflammation. Dr. Adam Numis then reads the e-Pearl of the week about nasociliary reflex. In the next part of the podcast, Dr. Chenjie Xia focuses her interview with Dr. Karen Roos on neurocysticercosis, its common manifestations, investigations and treatment.

Disclosures can be found at Neurology.org.

At Neurology.org, click on "RSS" in the Neurology Podcast box to listen to the most recent podcast and subscribe to the RSS feed.

CME Opportunity: Listen to this week's Neurology Podcast and earn 0.5 AMA PRA Category 1 CME Credits ${ }^{\mathrm{TM}}$ by answering the multiple-choice questions in the online Podcast quiz.

\section{$N E W !$ Breakthroughs in Neurology Conference}

Discover how to translate today's discoveries into tomorrow's clinic with six topic-intensive tracks, two plenary sessions focusing on year-in-review of the best science and education and controversial issues, and valuable information to help you prepare for your maintenance of certification recertification exam - all while earning up to 28.25 CME credits! The American Academy of Neurology's new Breakthroughs in Neurology Conference is set for January 23 through 25, 2015, at the picturesque Pointe Hilton Tapatio Cliffs Resort in Phoenix, AZ. Early registration and hotel reservation deadline is December 19.

Visit AAN.com/view/breakthroughs to secure your spot today! 


\section{Neurology}

\section{Mystery Case: Cerebral amyloid angiopathy-related inflammation \\ Aaron L. Berkowitz, Jessica M. Baker, Julie J. Miller, et al. \\ Neurology 2014;83;1678-1679 \\ DOI 10.1212/WNL.0000000000000930}

This information is current as of October 27, 2014

\begin{tabular}{|c|c|}
\hline $\begin{array}{l}\text { Updated Information \& } \\
\text { Services }\end{array}$ & $\begin{array}{l}\text { including high resolution figures, can be found at: } \\
\text { http://n.neurology.org/content/83/18/1678.full }\end{array}$ \\
\hline Supplementary Material & $\begin{array}{l}\text { Supplementary material can be found at: } \\
\text { http://n.neurology.org/content/suppl/2014/10/25/WNL.0000000000000 } \\
\text { 930.DC1 }\end{array}$ \\
\hline References & $\begin{array}{l}\text { This article cites } 2 \text { articles, } 1 \text { of which you can access for free at: } \\
\text { http://n.neurology.org/content/83/18/1678.full\#ref-list-1 }\end{array}$ \\
\hline Subspecialty Collections & $\begin{array}{l}\text { This article, along with others on similar topics, appears in the } \\
\text { following collection(s): } \\
\text { All Cerebrovascular disease/Stroke } \\
\text { http://n.neurology.org/cgi/collection/all_cerebrovascular_disease_strok } \\
\text { e } \\
\text { All Immunology } \\
\text { http://n.neurology.org/cgi/collection/all_immunology } \\
\text { MRI } \\
\text { http://n.neurology.org/cgi/collection/mri }\end{array}$ \\
\hline Permissions \& Licensing & $\begin{array}{l}\text { Information about reproducing this article in parts (figures,tables) or in } \\
\text { its entirety can be found online at: } \\
\text { http://www.neurology.org/about/about_the_journal\#permissions }\end{array}$ \\
\hline Reprints & $\begin{array}{l}\text { Information about ordering reprints can be found online: } \\
\mathrm{http} / / / \text { n.neurology.org/subscribers/advertise }\end{array}$ \\
\hline
\end{tabular}

Neurology ${ }^{\circledR}$ is the official journal of the American Academy of Neurology. Published continuously since 1951, it is now a weekly with 48 issues per year. Copyright () 2014 American Academy of Neurology. All rights reserved. Print ISSN: 0028-3878. Online ISSN: 1526-632X.

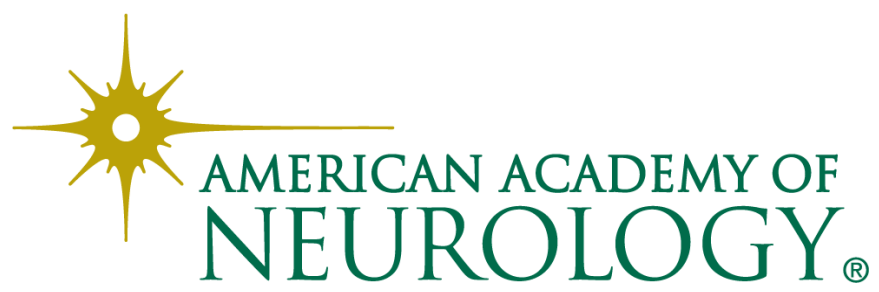

